Article

\title{
Emerging Markets Integration in Latin America (MILA) Stock market indicators: Chile, Colombia, and Peru
}

\author{
Edmundo R. Lizarzaburu Bolaños ${ }^{\mathrm{a}, *}$, Kurt Burneo ${ }^{\mathrm{b}}$, Hamilton Galindo ${ }^{\mathrm{c}}$, Luis Berggrun ${ }^{\mathrm{d}}$ \\ a Universidad ESAN, Lima, Peru \\ b Universidad San Ignacio de Loyola, Lima, Peru \\ c Universidad del Pacífico, Lima, Peru \\ d Universidad Icesi, Cali, Colombia
}

\section{A R T I C L E I N F O}

\section{Article history:}

Received 7 May 2015

Accepted 18 August 2015

\section{JEL classification}

G15

\section{Keywords:}

MILA

Integration

Risk

Emerging markets

\begin{abstract}
A B S T R A C T
This study aims to determine the impact of the Latin American Integrated Market (MILA) start-up in the main indicators of the stock markets of the countries that conform it (Chile, Colombia, and Peru). At the end, several indicators were reviewed to measure the impact on profitability, risk, correlation, and trading volume between markets, using indicators such as: annual profitability, standard deviation, correlation coefficient, and trading volume. The sample period runs from November 2008 to August 2013; and involves the three stock markets associated with MILA: Bolsa de Comercio de Santiago (BCS), Bolsa de Valores de Colombia (BVC) y Bolsa de Valores de Lima (BVL).

An additional evaluation for further research would consist of the calculation of relevant indicators to corroborate the validity of the effects found in this investigation corresponding to the integration of the stock exchanges of Lima, Santiago and Bogota, after the integration of the Mexican stock exchange that occurred in 2014.
\end{abstract}

(C) 2015 Universidad ESAN. Published by Elsevier España, S.L.U. This is an open access article under the CC BY-NC-ND license (http://creativecommons.org/licenses/by-nc-nd/4.0/).

\section{Indicadores de mercado de valores de la integración de mercados emergentes en América Latina (MILA): Chile, Colombia y Perú}

\section{R E S U M E N}

El presente estudio pretende determinar el impacto del Mercado Integrado Latinoamericano (MILA) en los principales indicadores del mercado de valores de los países que lo conforman (Chile, Colombia y Perú). Al final se revisaron varios indicadores para medir el impacto sobre la rentabilidad, el riesgo, la correlación y el volumen de operaciones entre mercados, por medio de indicadores como rentabilidad anual, desviación estándar, coeficiente de correlación y volumen de operaciones. El periodo de muestra se prolongó de noviembre de 2008 a agosto de 2013, e involucró a los tres mercados de valores asociados con el MILA: la Bolsa de Comercio de Santiago (BCS), la Bolsa de Valores de Colombia (BVC) y la Bolsa de Valores de Lima (BVL).

Una nueva evaluación para continuar el estudio podría consistir en el cálculo de los indicadores relevantes para corroborar la validez de los efectos revelados en esta investigación en materia de la integración de las bolsas de valores de Lima, Santiago y Bogotá después de la integración de la Bolsa Mexicana de Valores que tuvo lugar en 2014.

\footnotetext{
* Corresponding author.

E-mail address: elizarzaburub@gmail.com (E.R. Lizarzaburu Bolaños).
} 


\section{Introduction}

In the last decades, the financial sector has been gaining greater importance for the economies around the world. Stiglitz (2000) wrote about the capital market liberalization, and to identify their theoretical and empirical weaknesses. Moreover, the growth of financial companies has been faster than other industries; besides Levine (2002) found that the financial development is strongly associated with growth in develop countries. This growth is clear if finance importance is measured by its share of GDP, financial asset quantity, employment, or average wages in this sector (Greenwood \& Scharfstein, 2012). Besides, in the previous years, many academic studies have investigated the impacts of stock market liberalization and integration on the real economy (Bekaert \& Harvey, 1995; Bekaert \& Harvey, 2000; Panchencko \& Wu 2009).

Regarding the integration of markets, several studies indicate that it is a gradual process and takes many years with occasional reversal. Besides, requires major reforms in the financial sector, securities, economic and political processes and the ability of foreign investors to make direct investments (Carrieri, Errunza \& Hogan, 2007). The benefits gained are diverse, particularly economic, because integration accelerates the growth of the economies of the countries, have a support in times of crisis (Asness, Israelov \& Liew, 2011) and achieve decreasing transaction costs (Thapa \& Poshakwale, 2010).

Within this context, Chile, Colombia, and Peru have called the attention of worldwide investors during the last years. The greater dynamism of their economic activities, the deepening financial markets and solid results of stock markets have fostered the introduction of these markets in the global investment map (S\&P Dow Jones Indices, 2013). Likewise, the combination of improved public institutions related to finance and the reduction of barriers to capital movements have increased the flow of inward investment in the Andean countries, mainly Chile, Colombia and Peru.

The MILA (Mellado C, \& Garcia S, 2014) began operations in May 2011 and was the first market use virtual integration to combine markets in different countries to facilitate international transactions, within each independent market. The process was first conceptualized and agreed upon in September 2009 between the Santiago Exchange (Chile), The Colombia Exchange and the Lima Exchange (Peru) according to Mellado and García (2014).

These countries (Chile, Colombia, and Peru) are the leaders of foreign capital receipt, compared to other countries of the region, favoring the development of their financial markets according to BVL (2013). These three countries are the ones that precisely run the first integration effort of the stock markets at the level of the Andean countries, MILA, showing their development level and operational quality within this region. In recent years (2014), Mexican Stock Exchange became a member and other countries will explore to participate in order to develop the most significant stock exchange the Pacific Region. During the last ten years, markets composing MILA have experienced a significant growth both in an absolute and relative manner with Latin American markets and to a lesser extent to the emerging markets (S\&P Dow Jones Indices, 2013).

Even though market integration, dynamism, and efficiency of Andean countries are far from reaching the levels of the developed countries, a stable and sustainable development is evidenced in these sectors so important for the economic development of the region. Interest to examine the links between financial markets and economies is evident during the last decade. Interest to examine financial ties of the economies has increased due to global financial crisis from 2008 to 2009 (Babecky et al., 2012). The authors state that this economic and financial crisis brought greater awareness that the cost of financial integration is very important, and has such a high significance as the benefits of this. In this sense a critical factor is to have efficient regulation.
Fort this reason, it is interesting to analyze the situation at present of the financial markets in our region and especially in the capital market grew. This study aims to perform an empirical analysis of MILA implementation impact, and to establish a starting point to analyze the integration and development level that the involved markets have.

\section{Background}

According to the Department for International Development (D. F. S., 2004), the role the financial sector should play in society is to facilitate transactions and to enable credits and other financial products. The financial sector is a vital element for private sector development. This shows that in accordance with DFID, there is a close link between financial sector and private sector. Likewise, this institution states that the financial sector can play and important role to reduce risk and vulnerability and increase the capacity of individuals and households to access basic services like health and education, creating a more direct impact on poverty reduction.

Accordingly, Bekaert \& Harrey (1998) indicate that during the last twenty years, we have witnessed important changes in patterns shown by global capital flows with most dramatic changes in emerging markets. In the latter half of the 1980s and during the 1990s and 2000s, even to date, several emerging economies started a reform process to open their capital markets. Between these economies are Chile, Colombia, and Peru, among others within the region, in a process of market liberalization. The ongoing banking process in Peruvian economy leads the financial sector to take an increasing key role as one of the sectors on which the country economic growth depends. In developed countries, this sector is one of the most important within productive activities.

Besides, "the Inter-American Development Bank established five Institutional Priorities, which include regional and global integration. This priority reinforces the Bank's support for integration efforts in the region, including the Pacific Alliance, which the Bank has supported since its beginning. Recently, this alliance reinforced its commitment to financial integration at the IV Summit of the Pacific Alliance, held in Paranal, Chile, stating their support for the integration of Mexico 's Stock Exchange with the Latin American Integrated Market (MILA, for its Spanish initials), composed of the stock exchanges of Chile, Colombia, and Peru" from Framework of the 9th General Capital Increase (GCI-9), the Inter-American Development Bank.

In this context, the development of a solid capital market helps ensure a source of continuous and complementary funding to support business continuity within the region. In addition, globalization of the international financial sector has enabled Peru and other emerging countries of the region to reach a growing share of direct and indirect foreign investment. That is why it is convenient for nations to have an attractive capital market for all, both for domestic and foreign investors. There is a series of concepts established regarding portfolio theory and capital markets. When it comes to non-domestic investment, these take into account international dimensions; however, the same basic principles of domestic investments are applied (Bartram \& Dufey, 2001).

In the world of finance, foreign investors decide the destination of their investments following certain basic financial parameters such as: required profitability, investment risk, and liquidity of markets. In accordance with this, to compete in the international sector with a stock exchange limited by the size and frequency of negotiation is very difficult. For example, in the region, Sao Paulo Stock Exchange (BOVESPA) has overshadowed other regional markets due to its magnitude, being the main magnet for investment flows coming from outside the region. 


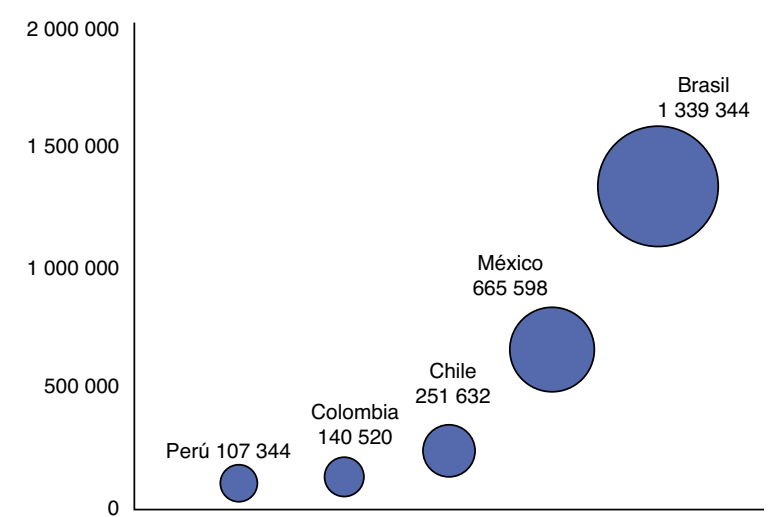

Figure 1. Market Capitalization of 2009 (US\$)

Source: Federación Iberoamericana de Bolsas (Iberoamerican Exchange Federation).

Due to its size and level of liquidity it makes other markets, like Santiago de Chile, Bogota, and Lima, almost imperceptible to foreign investors. As shown in Figure 1 and Figure 2, when we compare the size and liquidity of the Brazilian market in 2009 and 2012, there is a big difference between it and other markets within the region.

In contrast to Brazil, Peru is one of the smallest markets due to its market capitalization and in terms of dynamics, due to its trading volume.

Another key factor behind this integration process is a trend toward globalization of financial markets, which is more integrated every day. In the same line of thought, Agénor (2003) states that a key factor underlying the financial integration process is the search of investors for markets with higher rates of return than in their countries, and an opportunity of diversification in increasingly open and dynamic markets; all this, along with the concern of developing countries to attract more foreign capital flows. Thus, there is a latent need for regional markets integration, being MILA a first response to this need.

Hogue (2011), states that MILA objective is to create economies of scale and to allow a greater scope for the trading of shares in stock markets and companies operating in the participating countries. Likewise, the author says that with this integration effort, there is an opportunity to increase diversification. This should produce risk reduction for market participants, thus risk premiums required and capital cost for regional issuing companies would decrease. Integration may also reduce the bid-ask spread through transaction cost reduction and liquidity increase. Notwithstanding the predominance of certain types of actions related to specific productive sectors can slow down the process of integration.

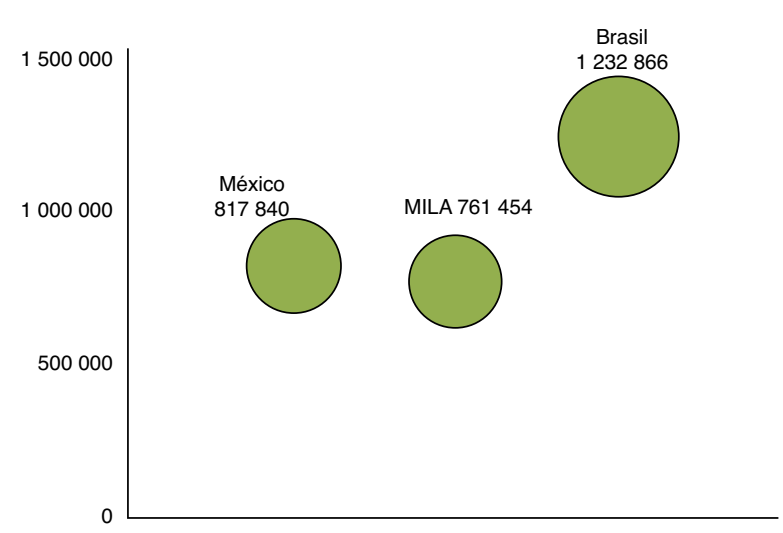

Figure 2. Market Capitalization of 2012 (US\$)

Source: Federación Iberoamericana de Bolsas (Iberoamerican Exchange Federation).
It is important to highlight that financial market integration does not only include capital market integration but money market, conforming the financial market.

\section{Literature review}

\subsection{Financial market}

According to (Parejo, García, \& Gámir, 2004), a financial market is the system or place whereby a financial asset exchange is produced and prices are determined. Initially, the system does not require a concrete physical space where this exchange is made. Recent studies (Kenett et al., 2014) have investigated large data sets of financial markets, and have analyzed and modeled the static and dynamic behavior of this very complex system (Fama, 1965, Lo \& Craig MacKinlay, 1990, Voit, 2005, Sinha, Chatterjee, Chakraborti, \& Chakrabarti, 2010, Abergel, Chakrabarti, Chakraborti, \& Mitra, 2011, Takayasu, 2006, Sornette, 2004).

As these authors mentioned, the main actions a financial market fulfills are: (i) to connect agents involved, natural or legal persons; (ii) be an appropriate mechanism for the pricing of assets, (iii) to provide liquidity to assets, since the market is more dynamic every day, assets can become cash more easily; and finally, (iv) shorten the time limits and costs of intermediation, in other words, be the appropriate channel for quick communication between agents participating in the market.

However, some markets fulfill this role better than others. Thus, the other markets are constantly compared and you can easily identify certain characteristics to those markets that play their role in an outstanding way.

A financial market will be more efficient when it better fulfills the group of corresponding functions, or when it most resembles a perfect competitive market. A perfect market is indeed a market in which there is perfect mobility of factors, where purchasers and sellers know every supply and demand and other market conditions, every agent can participate freely, and pricing is performed in terms of supply and demand, without outside intervention misleading its free information (Parejo et al., 2004).

The efficient market hypothesis (EMH) literature (Lee 2001) is careful to condition this statement on a particular set of available information (Fama, 1965, 1991). Obviously when financial assets are traded heterogeneous, this is contrary sense of the profiling of a perfectly competitive market. On the other hand, market efficiency can be defined considering some characteristics, such as: (i) amplitude, (ii) transparency, (iii) freedom, (iv) depth and, (v) flexibility.

\subsection{Financial integration}

According to some theories explain by Edison et al., 2002, IFI facilitates risk-sharing and thereby enhances production specialization, capital allocation, and economic growth (Obstfeld, 1994; Acemoglu and Zilibotti, 1997).

For Agénor (2003), the level of financial market integration has been increasing during the latter half of the 1980s and during the 1990s. Besides, he states that there are several factors which have converged to make this integration possible: (i) on one hand, the search for higher returns for investments and diversification of risk in international markets, driven by investors. (ii) At the same time, the effort of lots of emerging markets to foster foreign capital inflow, removing and reducing restrictions and controls on capital inflow and outflow. (iii) Deregulation of financial markets and, finally, (iv) improving the ecosystem and growth prospects by implementing free market oriented reforms. 
As Agénor (2003) states, costs and benefits can be seen from two perspectives: from the perspective of an investor and from the perspective of the country starting the integration process. From countries' perspective, the author lists a series of benefits and potential costs for this integration.

According with Ho and Dinh (2010) in this study they indicates that "Gurnain (2007, p.20) shows that the integration level of emerging markets has been improved although the progress comparatively slow compared to industrialized countries. According to García-Herrero and Wooldridge (2007, p.57), the financial markets of emerging countries have turned to be increasingly integrated into international financial systems in the early 1990s".

\subsection{Capital market and regulated markets}

In its broadest sense, capital can be defined as accumulated wealth engaged in a reproductive process (Chisholm, 2003). This defines that capital markets are physical or virtual spaces where participants who are seeking additional capital and those wishing to invest their excess resources are. He also defines capital market as places where risk can be distributed, shared, and diversified.

Vargas and Bayardo (2013) indicate that "Economic growth is linked to the phenomenon of globalization and carries a positive effect on market unification. The integration of the stock markets of Peru, Chile and Colombia carried consequences both inside and outside of the markets themselves, which have an impact on the participants, generating benefits and difficulties, with consequences in the operational aspects of this market".

On the other hand, Madura (2010) states that a capital market is a place where any stock certificate issued as a result of an initial or secondary public offer, can be commercialized by investors.

Stocks issued by a company are certificates representing the partial ownership of the company. Companies generally issue stocks in the primary market to have long-term fund to finance the expansion of its operations.

Slee (2011) states that capital markets are places where debt and private equity investments are made and private corporate interests are exchanged. He also says that valuation (of companies) is a common language between local or foreign market participants uniting capital markets at a global level. In other words, common language developed in private company valuation enables market participants to communicate and exchange interests.

In the capital market equity shares are traded on both the primary and secondary markets. Madura (2010) states that in the case of a public company it has two effects for the company: the first, the change of the property structure, since owners' quantity increases. The second, the change of the company capital structure since it increases the equity investment in the company.

According to Madura (2010), investors may be classified as individual and institutional. Individual investors are those natural persons having company stocks as investment vehicle, and institutional investors are legal persons having stocks for investment and operations purposes. Generally, institutional investors have more resources to invest and monitor investments made in a deeper way than those made by an individual investor.

Stock markets are markets regulated by a specialized market (in the case of Peru, by the Superintendencia de Mercado de Valores (Stock Market Superintendence, SMV) and in the US, by the Securities and Exchange Comission (SEC). According to Madura (2010), each organized market has a trading floor where floor traders make transactions in the secondary market for different clients.

Organized markets are centralized markets where there used to be a trading floor. Sale of securities and purchasing took place there. However, nowadays many organized markets do not have a physical space where negotiation can be made such as the most centralized market of the world, the New York Stock Exchange (NYSE); today, many markets are electronic.

Electronic negotiation is made electronically, purchase and sell orders are entered in a negotiation system (ELEX system in the case of Lima Stock Market but it is important to indicate that the platform name will change in 2015) and they are matched automatically following some parameters. Without a doubt, these kinds of markets reduce transaction costs significantly.

Madura (2010) states that, in that respect, many electronic stock markets were created in the mid-nineties to make electronic stock market transactions. These markets are known as electronic communication networks (ECN). It is worth highlighting that this is the type of market which will be studied in this document.

\section{Latin American Integrated Market (MILA)}

The integration process of stock markets of Chile, Colombia and Peru is the result of the agreement signed between the Santiago Stock Exchange (BCS), Colombian Securities Exchange (BVC, 2013), and Lima Stock Exchange (BVL), as well as Deceval (Colombian Centralized Securities Depository), Depósito Central de Valores (Colombian Central Securities Depository), and Cavali (Peruvian Central Securities and Settlements Registry). Operations started officially on May 30, 2011 and many opportunities were opened for investors and intermediaries from Chile, Colombia, and Peru, who can negotiate today cost-efficient stocks of the three aforementioned stock market locations through a local intermediary.

MILA is the first worldwide executed integrated market without corporate merger or integration (BVL, 2013). This form of integration is possible due to the use of technological tools and standardization of regulations on capital market negotiation and securities custody between the three participating nations (MILA, 2013).

Some authors made studies focused in analyses common factors in the stock markets of the member countries of the Latin American Integrated Market (MILA), Chile, Colombia and Peru, with the purpose of exploring the existence of a possible financial integration that would affect diversification benefits for investors (Romero et al., 2013) and others, focus in the integration of the stock markets and their consequences both inside and outside of the markets themselves, which have an impact on the participants, generating benefits and difficulties, with consequences in the operational aspects of this market (Vargas and Bayardo 2013).

According to MILA (2013), the following reasons explain this integration: (i) stock markets pretending to join are leading institutions in each market, (ii) the growing interest of participating countries in cross-investments, (iii) high expectations for economic growth, and (iv) the presence of complementary stock markets.

One of the most important characteristics at organizational level is that this integration does not deprive any market of its regulatory independence or autonomy. Nevertheless, shared and sustained growth in an integrated market is foreseen in a more increasingly standardized framework. It is vital to highlight that regarding MILA effectiveness, (Molina Castilla, N., Pabón Gutiérrez, J. D., Patiño, E., \& Alonso, M. -2012) state that for this integrated market to be effective, there must be a system that automatically lists foreign securities which are registered in foreign stock markets and in public records of participating countries.

MILA operations aim to simplify and improve the efficiency of share negotiation between investors of the three integrated markets. Every negotiation is made using the local currency of the investor's country or foreign currency, in the event that it is the currency in which the instrument is referred to, and with account entries through a local intermediary using a technological tool. 
Nowadays, it is the first market by number of companies listed in Latin America, the second in market capitalization size, and the third by negotiation volume at 2013. Regarding the participants of this integration model, (Molina Castilla, N., Pabón Gutiérrez, J. D., Patiño, E., \& Alonso, M. - 2012) mention the following stakeholders:

- The stock markets of each country: which are the authorized and entitled complying with a signed agreement.

- Depositories of each country: (Cavali, DCV, 2011, Deceval) having interconnection agreements for clearing and settlement of operations made within this market.

- Intermediaries (stock brokerages): making intermediation between investors and markets and having intermediate routing agreement with other participating intermediaries.

- Investors: represented by any entitled natural or legal person planning to invest in one or more markets.

- Regulatory entities: responsible for the supervision and regulation of the market and every operation made within it.

\section{Some characteristics of economies participating in MILA}

\subsection{Chile}

Chile's economy is characterized by a high level of openness in general and especially of foreign trade and strong financial and political institutions giving them a solid rating for sovereign bonds (CIA, 2013).

In 2013, exports of Chile represented the third part of the GDP, and copper only provides $19 \%$ of the government revenues. One of the main characteristics of Chilean economy is that is has a stock market able to meet on time the financing needs of companies within its market. (CIA, 2013). Chilean stock market has a concentration in its composition in shares of the consumer, financial and energetic industry, Chile has 22 trade agreements with 60 different countries including the European Union, Mercosur, China, India, South Korea, Mexico, among others. In addition, it is participating in the negotiation of Trans-Pacific Partnership free-trade agreement (CIA, 2013).

\subsection{Colombia}

The economy of Colombia is characterized by its rapid growth during the last ten years; a period when this country could consolidate one single centralized stock market for variable-yield securities negotiation, where hydrocarbon and mining sector prevails due to market capitalization. Thus, managed to prop up its stock market as the fourth location in Latin America (CIA, 2013).

Consistent economic policies and free-trade agreements promotion have increased their answer level to externalities impacting on local economy. Currently, the three main rating agencies have improved sovereign debt rating of the Colombian government to investment grade. On the other hand, the Colombian economy is heavily dependent on oil exports becoming vulnerable towards the fall in the price of this commodity (CIA, 2013).

Colombia has a free trade agreement with the USA which was ratified by the Congress in October 2011 and implemented in 2012. In addition, it has signed agreements with different countries including Canada, Chile, Mexico, Switzerland, the European Union, Venezuela, South Korea, Turkey, Japan, Costa Rica, Panama, and Israel (CIA, 2013).

\subsection{Peru}

The macroeconomic policy consistency and the rapid economic growth during the last years (the average growth rate of GDP was double in Latin America), make the Peruvian stock market a sector with great projection. Peruvian economy reflects the wide variety of geographical conditions existing in the country. A wide range of mineral products available in the Andes and coastal areas, a marine extension rich in hydro biological resources, and arable fertile and highly productive lands make Peruvian exports to focus on product exports coming from the exploitation of these resources (CIA, 2013).

Peruvian economy has been increasing at an average of $6.4 \%$ each year since 2002, with a stable appreciation of local currency until the end of 2013 and low inflation rates. Despite the solid macroeconomic fundamentals, Peruvian economy heavily depends on mineral exports and food imports. This situation makes it vulnerable to the fluctuations of these products international prices which, added to the lack of infrastructure to promote domestic trade, represent the main weaknesses of the national economy (CIA, 2013).

For a better understanding of the aforementioned, see the comparative table of the three economies during 2013, in Table 1 Comparison of Chile, Colombia, and Peru economies.

\section{Analyzed variables}

\subsection{Profitability}

Autorregulador del Mercado de Valores de Colombia (AMV, 2012, Colombia's Stock Market Self-regulator) states with regard to investments in the stock market, when we perform an investment in the stock market, we want to earn as much money as possible from the capital we have invested. Thus, investment offering greater profitability is pursued. AMV (2012) says that profitability is the economic benefit we can receive from an investment. It is usually measured as the percentage from the amount earned divided by the invested capital, during a specific period of time.

Richards (2013) explains regarding the calculation of asset profitability, whereas an asset is acquired in moment $t_{0}$ for a price $P_{t 0}$ and it's sold at the time $t_{1}$ for a price $P_{t 1}$. If there is no flow of money in the intermediate period between $t_{0} \mathrm{yt} t_{1}$, return ratio between both periods $R\left(t_{0}, t_{1}\right)$ is the percentage change between both prices and it's calculates as follows:

$R\left(t_{0}, t_{1}\right)=\frac{P_{t_{1}}-P_{t_{0}}}{P_{t_{0}}}$

In order to simplify the profitability analysis in the stock markets, this method has been chosen for profitability measuring purposes during the period $\left(t_{0}, t_{1}\right)$.

\subsection{Risk}

AMV (2012), states that profitability and risk usually move in the same direction. We must be aware that to have a greater profitability, we need to be able to take increased risks. To know how risky an investment is, there are different measuring mechanisms. One of the most used is volatility measuring the increase or reduction of an asset price in a set period of time. It is technically defined as the measure of how far the asset price is separated from its average price.

Melo and Becerra (2005) explain that there are different methods to measure the risk of an asset or portfolio. One way is through the probability distribution function of assets losses and profits using estimators of certain parameters of this distribution such as the standard deviation. Melo and Becerra (2005) say that one simplified way to measure the risk of an asset is through the volatility of its returns since an asset has high volatility, the result can have greater uncertainty. One possible approach to volatility is the asset standard deviation. 
Table 1

Comparison of Chile, Colombia, and Peru economies (2013).

\begin{tabular}{|c|c|c|c|}
\hline Item & Chile & Colombia & Peru \\
\hline Population & $17,216,945$ & $45,745,783$ & $29,849,303$ \\
\hline Currency & Chilean Peso & Colombian Peso & New Sol \\
\hline $\begin{array}{l}\text { PBI PPP } \\
\text { (US\$ million) }\end{array}$ & 308,900 & 511,100 & 332,000 \\
\hline $\begin{array}{l}\text { Per capita GDP } \\
\quad \text { (US\$ millions) }\end{array}$ & 18,700 & 11,000 & 10,900 \\
\hline Growth & $5.50 \%$ & $4 \%$ & $6.30 \%$ \\
\hline $\begin{array}{l}\text { Gross national savings } \\
\text { (\% of GDP) }\end{array}$ & $21.40 \%$ & $20.40 \%$ & $23.20 \%$ \\
\hline $\begin{array}{l}\text { Net reserves in FC and gold } \\
\quad \text { (US\$ millions) }\end{array}$ & 41,650 & 370,000 & 64,170 \\
\hline $\begin{array}{l}\text { External debt } \\
\quad \text { (US\$ millions) }\end{array}$ & 104,600 & 82,420 & 43,520 \\
\hline Unemployment & $6.40 \%$ & $10.40 \%$ & $6.80 \%$ \\
\hline Population below poverty line & $15.10 \%$ & $34.10 \%$ & $27.80 \%$ \\
\hline First export products & $\begin{array}{l}\text { Copper, fruits, fish based products, } \\
\text { paper and pulp, chemical products, } \\
\text { wine. }\end{array}$ & $\begin{array}{l}\text { Oil, coal, emeralds, coffee, } \\
\text { nickel, cut flowers, bananas, } \\
\text { and clothing accessories. }\end{array}$ & $\begin{array}{l}\text { Copper, gold, lead, zinc, aluminum, iron, } \\
\text { molybdenum, crude oil, oil derivatives, } \\
\text { natural gas, coffee, asparagus, other } \\
\text { vegetables, fruits, textile accessories and } \\
\text { products, fishmeal, fish for human } \\
\text { consumption, chemical products. }\end{array}$ \\
\hline
\end{tabular}

Source: The CIA World Factbook (2013).

\subsection{Correlation}

Several studies support some benefits of international diversification because they assume that the correlations are generally constant; however, empirical evidence shows otherwise. Studies by Makridakis and Wheelwrigth (1974) and Longin and Solnik (1995) describe the instability in the correlations between international markets. Recent research also suggests rejecting the hypothesis of constant correlations, highlighting the results of Wong and Vlaar (2003), Bekaert, Hodrick and Zhang (2009).

The measurement basis of integration degree of two or more markets used by many authors is the shared risk factors analysis which helps determine if these countries face the same market, with access to the same instruments and services; in addition to the same regulations and political framework (Romero et al., 2013). Glick and Rose in particular find that currency crises tend to spread within regional geographies (Mellado C, Garcia S, 2014).

Besides, Fenn et al. (2011) indicate that the global financial system is a group of very different markets distributed along different geographic locations, where a wide variety of financial products are traded. Despite the diversity of markets and the difference of the traded products nature, changes in asset prices frequently answer the same economical advertisements and news in the markets. This situation implies that there is a strong price coupling so, temporary series of prices can show similar characteristics and be correlated. Thus, there is literature describing the correlation analysis as a way to define how integrated is a market with another, especially in stock markets, where the index provide a universe of data easy to quantify and analyze.

\subsection{Volume}

Schwert (1990) states that negotiation volume prompts a change in the asset price since this change represents an important input in negotiation strategies. There is evidence that operations increase and volatility in share return happen at the same time. Some observers conclude that operations volume is a direct cause of volatility.

Regarding the question coming from this statement: What causes that many people want to operate at the same time and in the same direction? The author indicates that one possible answer is the arrival of new information leading investors to come to a conclusion if prices are very high or low. On the other hand, Brailsford (1994) says that there is significant interest in understanding how negotiation volume is related to price movement in stock markets. It is clear that positive negotiation volumes are necessary to create a price movement observable in the market. This way, we can identify a relationship between the negotiation volume of an asset and its volatility and profitability.

Furthermore, from this relationship defined as symmetrical and asymmetrical by different authors, the negotiation volume gives a clear indicator of market liquidity where participation takes place.

Thus, measure the asset liquidity risk held in portfolio or that want to be analyzed. It is worth mentioning that liquidity risk translates into the difficulty of selling or liquidating an investment. There are shares difficult to sell since they are less demanded by the market; despite the fact that the issuer is a successful company (AMV, 2012).

We can avoid settle risk by knowing the tools which help to identify less demanded shares. For this purpose, negotiation volume should be considered measuring "how much a share has been negotiated in the market (in a specific period of time)." This helps to establish how liquid the market is for our asset.

For this study, the monthly negotiation amount and the number of monthly operations will be used to quantify the negotiation volume in the market.

\section{Results}

\subsection{Profitability}

Profitability of MILA markets was decreasing and the implementation of agreements did not impact significantly on its trend. This is shown in the slight variation of the calculated slope (Figure 3 ). On the other hand, profitability of IPSA index demonstrates a slow fall and has no significant changes in the slope explaining the trend (Figure 4).

Likewise, COLCAP index profitability shows a clear negative trend before the implementation; after the implementation this trend settles and becomes slightly positive. Thus, a slight positive impact can be shown (Figure 5).

In the case of IGBVL (General Index of the Lima Stock Exchange), it has been showing a negative trend with zero impact despite the implementation of integration agreements (Figure 6). If we see 


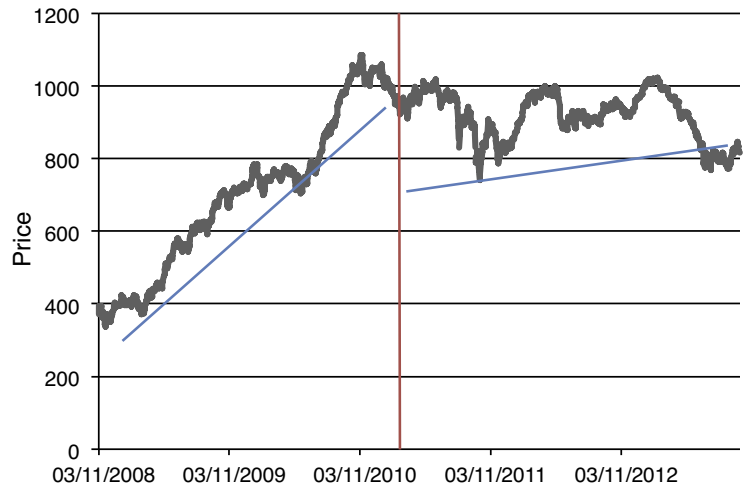

Figure 3. Historical development of S\&P index MILA 40 Source: Federación Iberoamericana de Bolsas (Iberoamerican Exchange Federation).

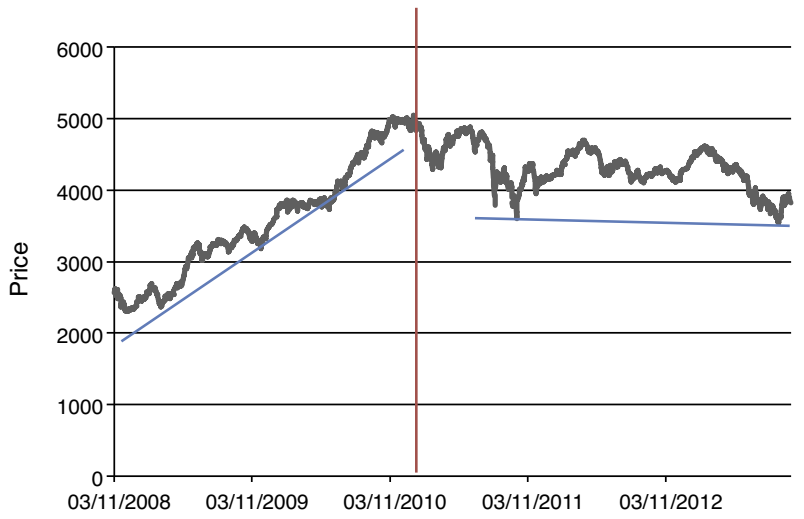

Figure 4. Historical development of IPSA index

Source: Federación Iberoamericana de Bolsas (Iberoamerican Exchange Federation)

in general terms the implementation of MILA, the average rate dynamics would have been reduced and even in the case of the General Rate of the Bolsa de Valores de Lima, the integration would be associated with a shift in the slope of evolution of the rate.

In every figure we can see a turning line drawn vertically which represents the moment MILA started working officially.

\subsection{Volatility}

Volatility of the integrated market has shown a negative trend, in other words, it has a trend towards stabilization. However, it did not show a significant impact after the implementation of

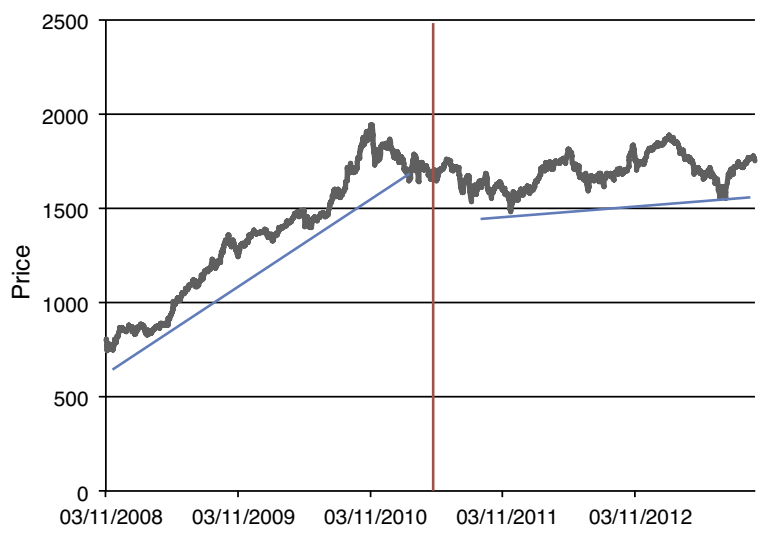

Figure 5. Historical development of COLCAP index

Source: Federación Iberoamericana de Bolsas (Iberoamerican Exchange Federation).

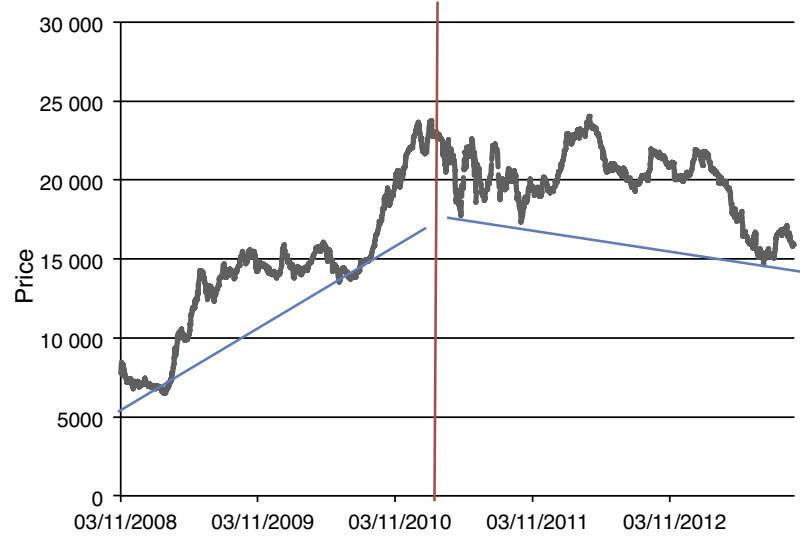

Figure 6. Historical development of IGBVL

Source: Federación Iberoamericana de Bolsas (Iberoamerican Exchange Federation).

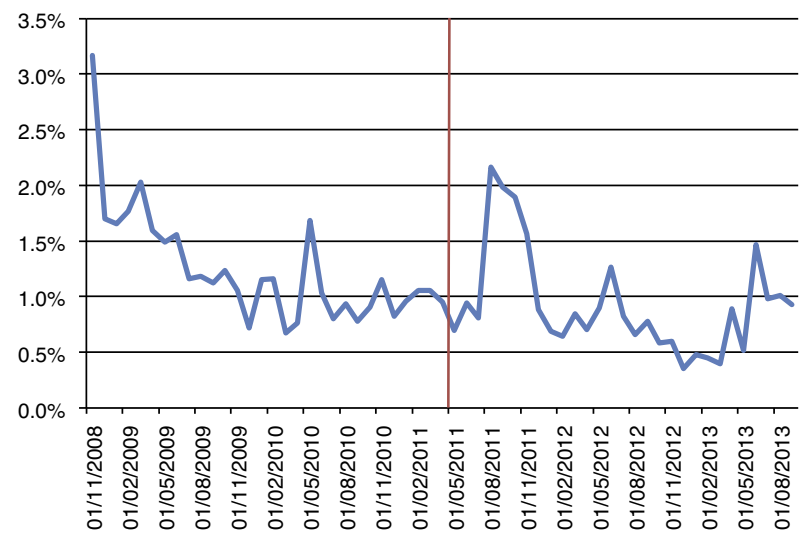

Figure 7. Monthly standard deviation of S\&P MILA 40 Preparation: Authors.

integration agreements keeping the same trend since before the event was studied.

Impact on volatility will be determined using monthly standard deviation of daily percentage variations of S\&P MILA 40 index and individual rates. IPSA index volatility, like MILA, has shown a negative trend which have not been impacted by the implementation of agreements (Figures 7 and 8).

The situation of COLCAP index volatility is the same of every analyzed index (Figure 9). Volatility IGBVL index, like the others studied, shows a tendency worth mentioning, that the IGBVL is

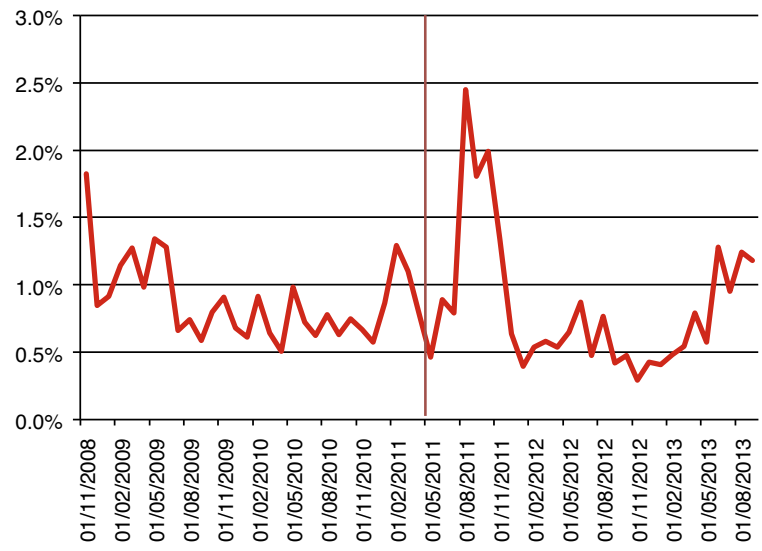

Figure 8. Monthly standard deviation of IPSA Preparation: Authors. 


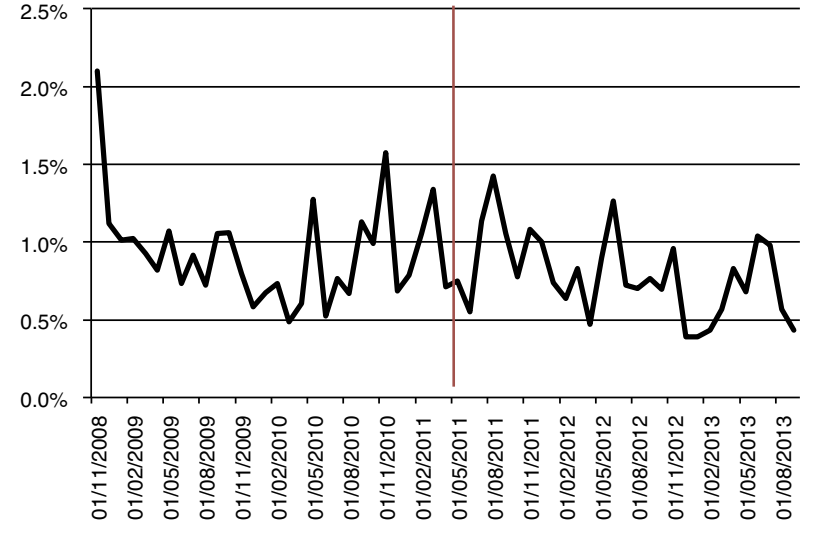

Figure 9. Monthly standard deviation of COLCAP

Preparation: Authors.

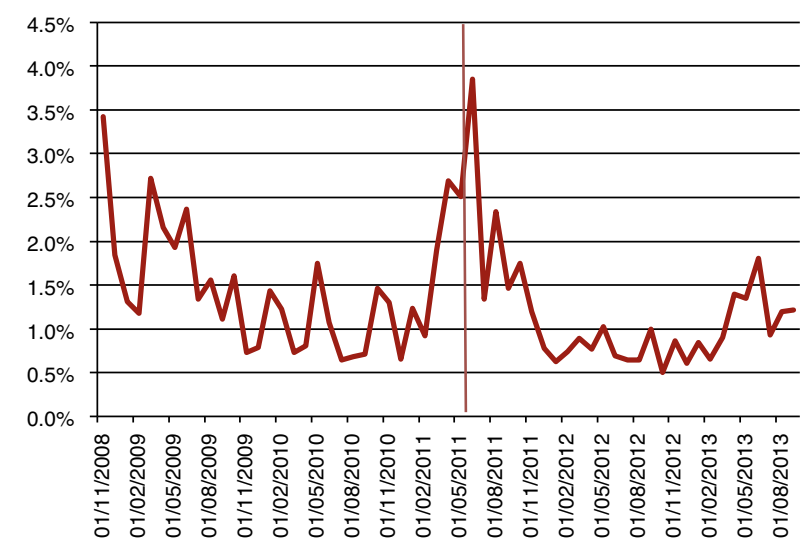

Figure 10. Monthly deviation of IGBVL

Preparation: Authors.

strongly influenced by the performance of mining stocks (60\%) facts which might explain the differentiation of volatility despite diversification (Figure 10). Apparently the lower volatility was marginal and can be explained by similar sectorial comparisons portfolio which serve to build stock indexes.

\subsection{Correlation}

To determine the correlation between the different markets, a correlation coefficient of the daily percentage variation of the price indexes of different markets was used. The correlation between IGBVL and COLCAP shows a negative trend without significant impact after the implementation of agreements.

On the other hand, the correlation between IGBVL and IPSA was tracing a negative trend before the implementation but after, the trend settled tracing an almost horizontal line. It is worth highlighting that these markets show a significant correlation in their markets and this trend was positively impacted after MILA implementation. The correlation between COLCAP and IPSA has shown a negative trend without a well-defined pattern after the implementation. Thus, it has no significant impact.

\subsection{Traded amount}

Regarding traded amounts, an interesting finding was made. On the opposite of the expected increase in the trading volume after the implementation of MILA, contrary impacts were produced. In general, MILA market was negatively impacted after the implementation regarding the amount traded together (Figure 11).

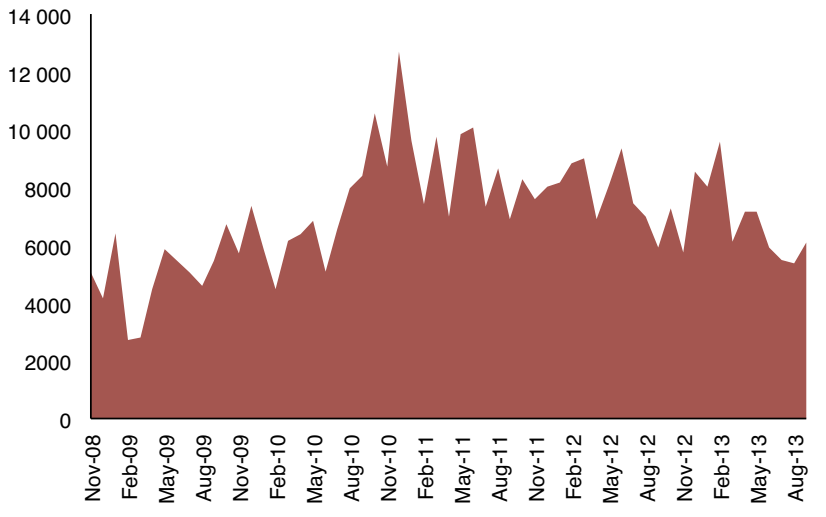

Figure 11. MILA development of the monthly traded amount (US\$ million) Preparation: Authors.

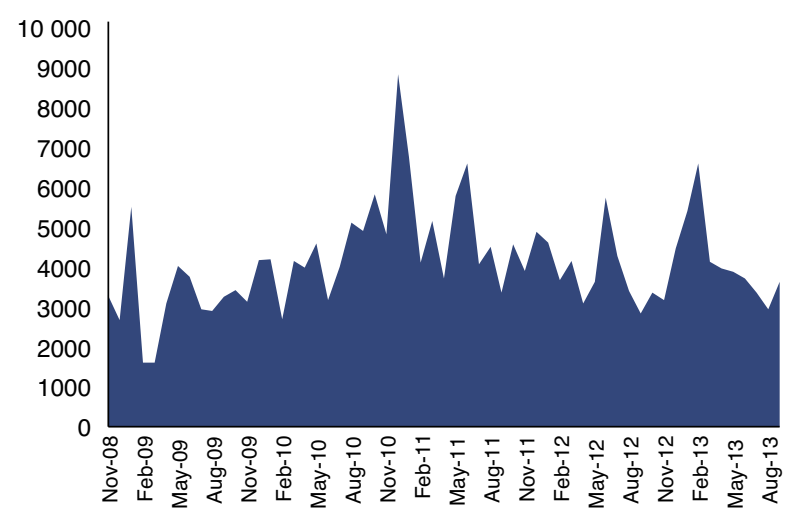

Figure 12. Chile Stock Market development of the monthly traded amount (US\$ million)

Preparation: Authors.

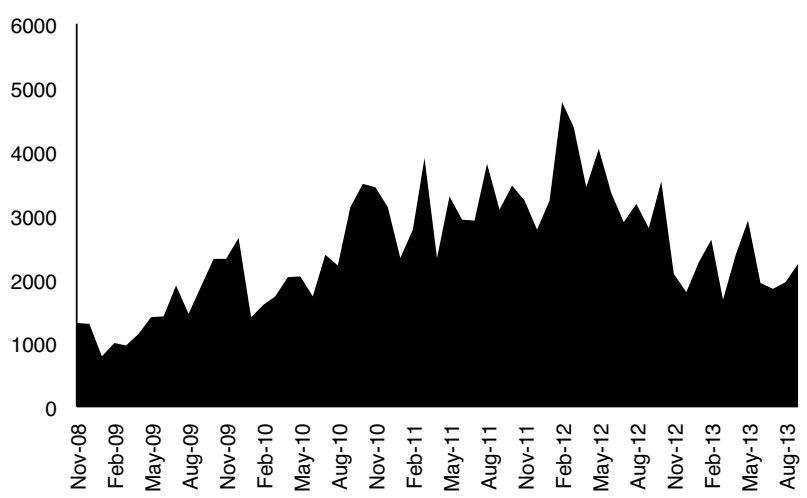

Figure 13. Colombia Stock Market development of the monthly traded amount (US\$ million)

Preparation: Authors.

The three markets were negatively impacted, but the Colombian has a greater change in its tendency.

Varying vertically downwards after the implementation (Figures 12-14), this change was due to the financial economic conditions of the region.

\subsection{Number of operations}

Regarding the number of operations, we found that MILA as well as the three markets separately, have been negatively impacted after the implementation of agreements in a way similar to the traded amount. This may suggest that the trend was more directed 


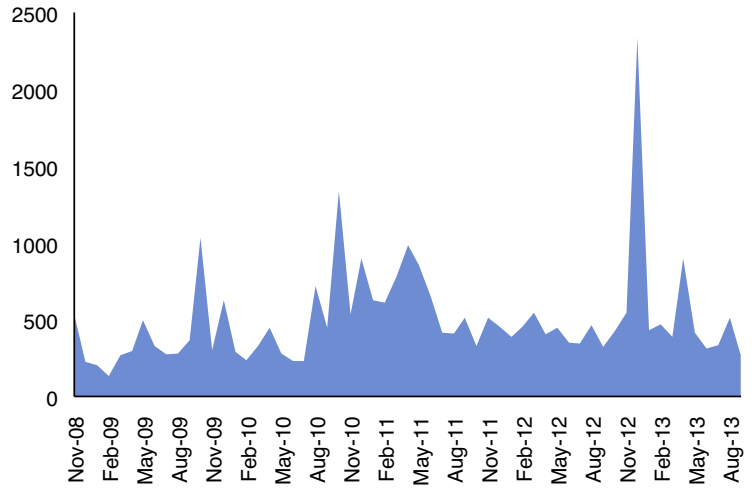

Figure 14. Lima Stock Market development of the monthly traded amount (US\$ million)

Preparation: Authors.

in accordance with the regional financial and economic environment of this period.

\section{Conclusions and recommendations}

In conclusion, the impact that MILA had, which has been evaluated from an empirical perspective, at the beginning of the integration process, would not have been as expected. The impacts in terms of profitability, risk and correlation have been marginal and the impact on the volume has been negative.

Should be noted that the results are limited since, this study does not have as assumption that other factors having implications in capital market (as interest rates, GDP growth, inflation, country risk, exchange rates, sectorial events among others) remain constant. So most of the results obtained here would explain only partially the impact to be measured. It is worth mentioning that this study was performed in early form, since the processes of integration of capital and financial markets in general are long processes, and a learning period is necessary for investors to gain the necessary experience to engage freely in every involved market.

Another observation from this study is that there are still factors avoiding the full integration of markets such as the differences in tax treatments in each participating country. These differences make transaction costs different in each market. Moreover, the subset of assets on which the indexes are built, are heterogeneous per sectors.

In contrast to these empirical findings, agreements for Mexico to integrate into MILA are moving forward (Perú 21 newspaper, November 2013). It is possible that by mid-2014 or 2015, the integration of one of the biggest Latin American stock markets can be achieved.

Besides, this integration could have a positive effects in the local Market Markets Program (Colombia and Peru), but it is important to evaluate the impact not only of regulatory aspects, but also monetary policies tools such as exchange rate and interest rate. Aspects such as carry trade could have a negative impact in the economies of these emerging markets.

One aspect to be evaluated in future research given the limited time elapsed after the integration of Bolsa de México (Stock Change of Mexico) to MILA, is to what extent the findings of this research are still valid given the incorporation in 2014 of a Stock like the Mexican one, which holds a higher volume of transactions and diversification; also additionally in a tentative agenda for further research, it could be established as control variables to key macroeconomic variables that affect the level and dynamics of stock indexes.

In addition, countries like Panama, Brazil which has the biggest stock market in Latin America, and Uruguay, have shown their will to integrate into MILA in the near future. Thus, the strategic importance is shown and MILA long-term vision, like the first integration initiative of Latin American stock markets.

Another conclusion, it is that the participant in MILA potentially benefits from increased stock choices and potential diversification. Maybe to modify the index could be an interesting alternative to explore.

\section{References}

Acemoglu, D., \& Zilibotti, F. (1997). Was Prometheus unbound by chance? Risk Diversification, and Growth. Journal of Political Economy, 105, 709-751.

Abergel, F., Chakrabarti, B., Chakraborti, A., \& Mitra, M.(2011). Econophysics of orderdriven markets. Springer.

Agénor, P. R. (2003). Benefits and costs of international financial integration: Theory and facts. The World Economy, 26(8), 1089-1118.

AMV. (2012). Conozca los riesgos del Mercado de Valores. Cartilla $\mathrm{N}^{\circ} 2$. Retrieved on November 15, 2013. from:http://www.amvcolombia.org.co/ attachments/data/20120605120911.pdf.

Asness, Clifford S., Israelov, Roni, \& Liew, John M. (2011). International Diversification Works (Eventually). Financial Analysts Journal, 67(3), 1-23.

Babecky, J., Komarek, L. and Komarkova, Z. (2012). Integration of Chinese and Russian Stock Market with world markets: National sectoral perspectives. Bank of Finland, BOFIT. Institute of Economies in Transition, (8).

Bartram, S. M., \& Dufey, G. (2001). International portfolio investment: Theory, evidence, and institutional framework. Financial Markets, Institutions E'Instruments, 10(3), 85-155.

Bekaert, G., \& Harvey, C. R. (1995). Time-varying world market integration. Journal of Finance, 50, 403-444.

Bekaert, G., \& Harvey, C. R. (1998). Capital flows and the behavior of emerging market equity returns (No. w6669). National bureau of economic research.

Bekaert, G., \& Harvey, C. R. (2000). Foreign speculators and emerging equity markets Journal of Finance, 55, 565-614.

Bekaert, G., Hodrick, R. J., \& Zhang, X. (2009). International stock return comovements. The Journal of Finance, 64, 2591-2626, 6.

Brailsford, T. (1994). The empirical relationship between trading volume, returns and volatility. Research paper, 94-101.

BVC. (2013). Metodología para el cálculo del índice COLCAP. Retrieved from: http:// www.bvc.com.co/pps/tibco/portalbvc/Home/Mercados/descripciongeneral/ indicesbursatiles?com.tibco.ps.pagesvc.action=updateRenderState\&rp.current DocumentID=13c20e3d_13d5f9d729a_7fcc0a0a600b\&rp.revisionNumber=1\& rp.attachmentPropertyName $=$ Attachment\&com.tibco.ps.pagesvc.targetPage $=$ 1f9a1c33_132040fa022_-78750a0a600b\&com.tibco.ps.pagesvc. mode=resource \&rp.redirectPage=1f9a1c33_132040fa022_-787e0a0a600b on August 8, 2015.

BVL. (2013). Preguntas frecuentes MILA. Retrieved from: http://www.bvl.com.pe/ mila/preguntas_frecuentes.pdf on September 15, 2013

Carrieri, Francesca, Errunza, Vihang, \& Hogan, Ked. (2007). Characterizing world market integration through time. Journal of Financial and Quantitative Analysis, 42(04), 915-940.

Chisholm, A. M. (2003). An introduction to capital markets: Products, strategies, participants. John Wiley \& Sons.

CIA. (2013). The World Factbook. Retrieved from: https://www.cia.gov/library/ publications/the-world-factbook/on September 15, 2013.

DCV (2011). Guía de Mercado Integrado MILA. Versión 3.

Fama, E. (1965). The behavior of stock market prices. Journal of Business, 38, 34-105

Fama, E. (1991). Efficient capital markets: II. Journal of Finance, 46, 1575-1617.

Fenn, D., Porter, M., Williams, S., McDonald, W., Johnson, N., \& Jones, N. (2011). Temporal evolution of financial market correlations. Physical Review, E 84, 026109.

García-Herrero, A., \& Wooldridge, P. (2007). Global and regional financial integration: Progress in emerging market. BIS Ouarterly Review, 57-70.

Greenwood, R. and Scharfstein, D. (2012). The growth of modern finance. Available in SSRN 2162179

Gurnain, P. (2007). Financial integration in emerging market economies MPRA Paper 5278, University Library of Munich, Germany (available at: http://mpra.ub.unimuenchen. de/5278/1/MPRA_paper_5278.pdf).

Hogue, J. (2011). MILA Integration report: Detailed analysis on exchange integration of Chile. Colombia and Peru: Efficient Alpha.

Levine, R. (2002). Bank-based or market-based financial systems: Which is better? Journal of Financial Intermediation, 11(4), 398-428.

Lo, A. W., \& Craig MacKinlay, A. (1990). An econometric analysis of nonsynchronous trading. Journal of Econometrics, 45, 181-211.

Longin, F., \& Solnik, B. (1995). Is the correlation in international equity returns constant: 1960-1990? Journal of International Money and Finance, 14(1), 3-26

Madura, J. (2010). Mercados e instituciones financieras/Financial markets and institutions. Cengage Learning Editores.

Makridakis, S. G., \& Wheelwright, S. C. (1974). An analysis of the interrelationships among the major world stock exchanges. Journal of Business Finance $\varepsilon$ Accounting, 1(2), 195-215.

Mellado, C., \& García, S. (2014). . The effects of the Latin American Integrated Market (MILA) on the foreign Exchange of Colombia (4) Peru and Chile: American Journa of Economics., 2A

Melo, L., \& Becerra, O. (2005). Medidas de riesgo, características y técnicas de medición. Una aplicación del VaR y el ES a la tasa Interbancaria de Colombia. Colombia: Banco de la República. 
MILA. (2013). http://www.mercadomila.com/componentes/imagenes/mila_news_ no_21.pdf.

Molina Castilla, N., Pabón Gutiérrez, J. D., Patiño, E. and Alonso, M. (2012). Descripción del impacto del mercado integrado latinoamericano MILA para las acciones de dos emisores del sector de hidrocarburos en Colombia. Chía-Cundinamarca: Universidad de la Sabana-Especialización en Finanzas y Mercado de Capitales.

Obstfeld, M. (1994). Risk-taking, global diversification, and growth. American Economic Review, 84, 1310-1329.

Panchenko, V., \& Wu, E. (2009). Time-varying market integration and stock and bond return concordance in emerging markets. Journal of Banking E' Finance, 33(6), 1014-1021.

Parejo, J. A., García, A. C., \& Gámir, J. A. P. (2004). Manual del sistema financiero español. Ariel, 12

Perú 21. (2013). México entraría al MILA a mediados de 2013. Retrieved on November 15, 2013, from: http://peru21.pe/economia/mexico-entraria-almila-mediados-2014-2152844.

Richards, R. (2013). Lecture notes on return calculation. Computational Finance and Financial Econometrics. University of Washington. Retrieved from: http://faculty.washington.edu/ezivot/econ424/returnCalculations.pdf.

Romero-Álvarez, Y. P., Ramírez-Atehortúa, F. H., \& Guzmán-Aguilar, D. S. (2013) Mercado Integrado Latinoamericano (MILA): análisis de correlación y diversificación de los portafolios de acciones de los tres países miembros en el período 2007-2012. Cuadernos de Contabilidad, 14(34).
Schwert, G. W. (1990). Stock market volatility. Financial Analysts Journal, 23-34 Sinha, S., Chatterjee, A., Chakraborti, A., \& Chakrabarti, B. (2010). Econophysics: An introduction. Wiley-VCH.

Slee, R. T. (2011). Private capital markets: Valuation, capitalization, and transfer of private business interests. John Wiley \& Sons.

Sornette, D. (2004). Why stock markets crash: Critical events in complex financial systems. Princeton University Press.

Stiglitz, J. E. (2000). Capital market liberalization, economic growth, and instability World development, 28(6), 1075-1086.

S\&P Dow Jones Indices (2013). Benchmarking MILA. McGraw Hill Financial. Retrieved from: http://www.spindices.com/documents/research/researchmila-40-spanish.pdf on June 19, 2014.

S\&P Dow Jones (2013). S\&P Dow Jones Indices: S\&P MILA 40 Methodology. Retrieved from: http://us.spindices.com/documents/methodologies/methodology-spmila-40.pdf?force_download=true on July 19, 2014.

Takayasu, H. (2006). Practical fruits of econophysics: Proceedings of the Third Nikkei Econophysics Symposium. Springer.

Thapa, Chandra, \& Poshakwale, Sunil S. (2010). International equity portfolio allocations and transaction costs. Journal of Banking \& Finance, 34(11), 2627-2638.

Voit, J. (2005). The statistical mechanics of financial markets. Springer.

Wong, A. S. K. \& Vlaar, P. J. (2003). Modelling time-varying correlations of financia markets. The Nederlandsche Bank NV Research Memorandum, 739, 0319. 